Prepared in Cooperation with the Lower Platte North and Lower Platte South Natural Resources Districts

\title{
Helicopter Electromagnetic and Magnetic Geophysical Survey Data, Swedeburg and Sprague Study Areas, Eastern Nebraska, May 2009
}

By Bruce D. Smith, Jared D. Abraham, James C. Cannia, Burke J. Minsley, Lyndsay B. Ball, Gregory V. Steele, and Maria Deszcz-Pan

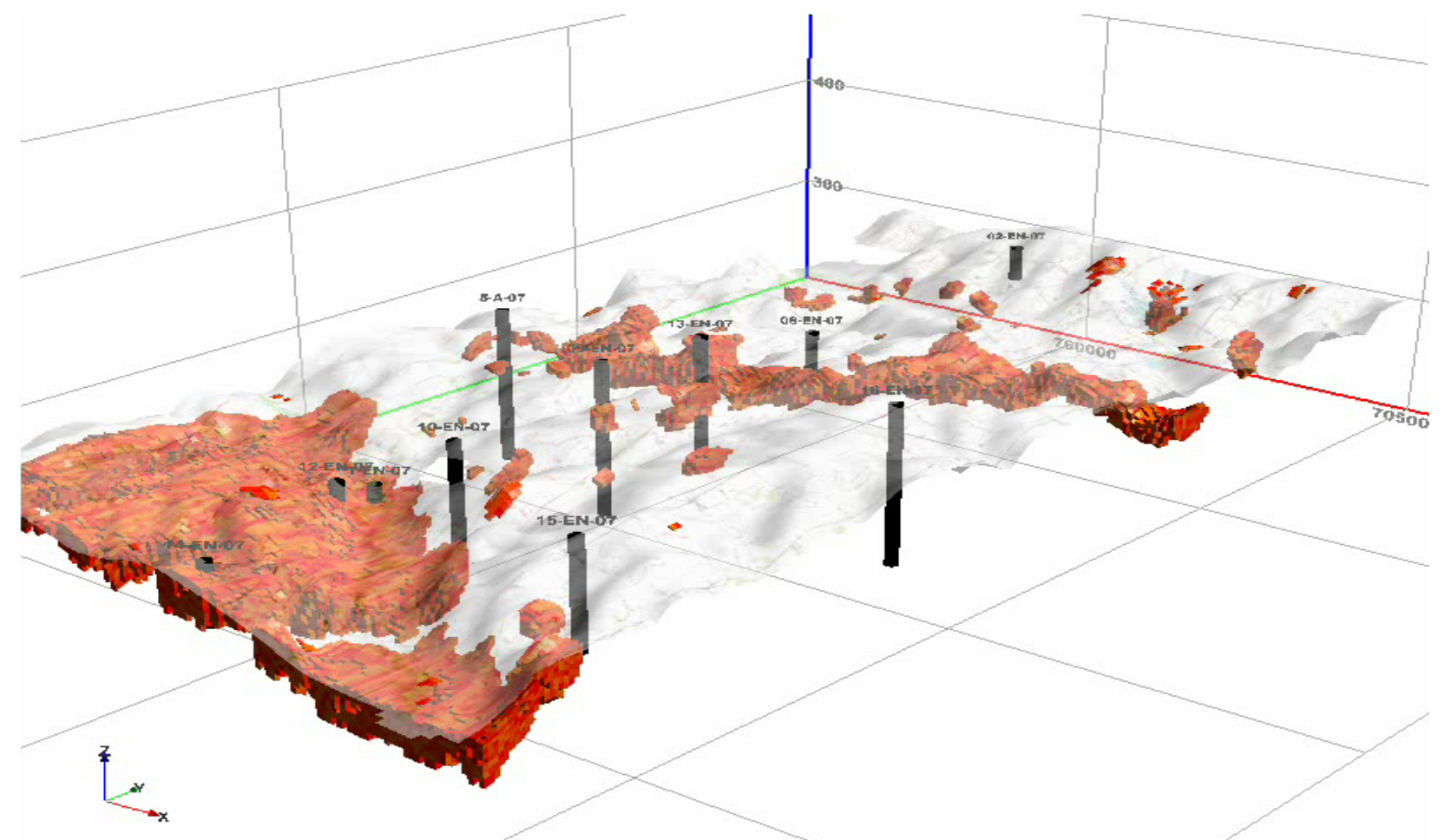

Open-File Report 2010-1288 Version 1.2 U.S. Department of the Interior U.S. Geological Survey 
THIS PAGE INTENTIONALY BLANK 


\title{
U.S. Department of the Interior KEN SALAZAR, Secretary
}

\author{
U.S. Geological Survey \\ Marcia K. McNutt, Director
}

U.S. Geological Survey, Reston, Virginia 2009

Revised and reprinted: 2011

For product and ordering information:

World Wide Web: http://www.usgs.gov/pubprod/

Telephone: 1-888-ASK-USGS

For more information on the USGS-the Federal source for science about the Earth, its natural and living resources, natural hazards, and the environment:

World Wide Web: http://www.usgs.gov/

Telephone: 1-888-ASK-USGS

Suggested citation:

Smith, B.D., Abraham, J.D., Cannia, J.C., Minsley, B.J., Ball, L.B., Steele, G.V., and Deszcz-Pan, Maria, 2011, Helicopter electromagnetic and magnetic geophysical survey data, Swedeburg and Sprague study areas, eastern Nebraska, May 2009: U.S. Geological Survey Open-File Report 2010-1288, 37 p.

Any use of trade, product, or firm names is for descriptive purposes only and does not imply endorsement by the U.S. Government.

Although this report is in the public domain, permission must be secured from the individual copyright owners to reproduce any copyrighted material contained within this report.

Front Cover: 3-D view of resistive material for the eastern side (Firth area) of the Crete-Princeton aquifer showing test holes drilled prior to the 2007 HEM survey to test aquifer geometry. 


\section{Contents}

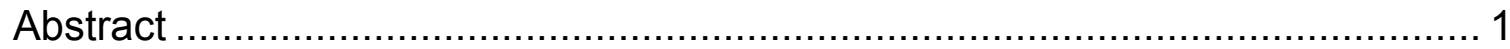

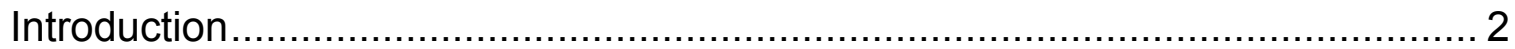

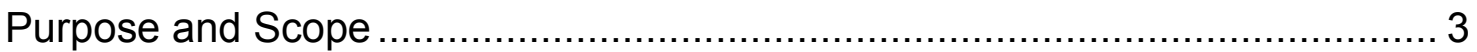

Description of Study Areas ...................................................................... 4

Airborne Geophysical Survey Overview ................................................. 7

Geophysical Data Overview ............................................................. 7

Helicopter Electromagnetic and Magnetic Survey ….................................... 10

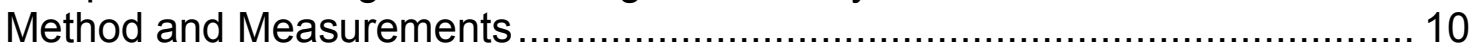

Electromagnetic Measurements ............................................................. 11

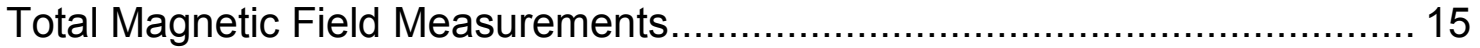

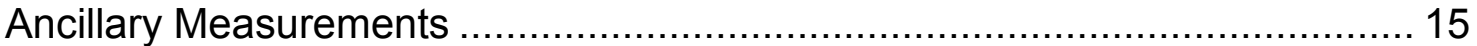

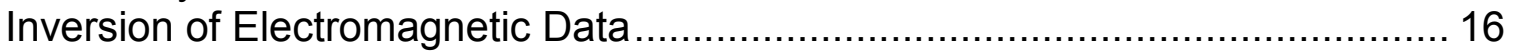

Testing to Determine Optimal Inversion Parameters .................................. 18

Model Assessment Using the Depth of Investigation (DOI) Metric ................. 20

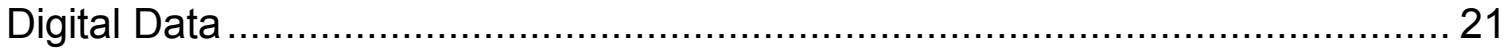

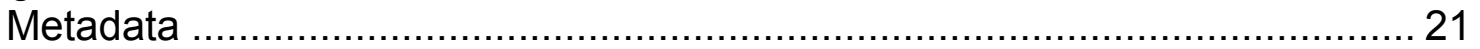

GIS Data

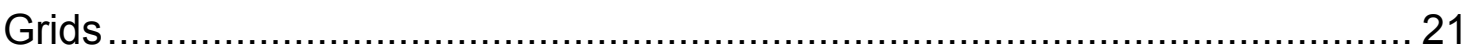

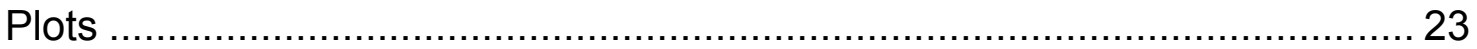

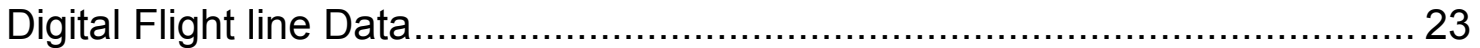

Keyhole Markup Language (KML) Files ……........................................ 23

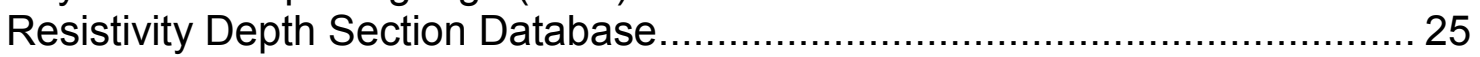

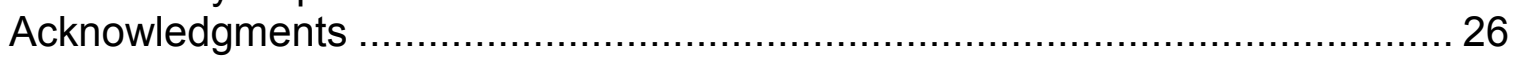

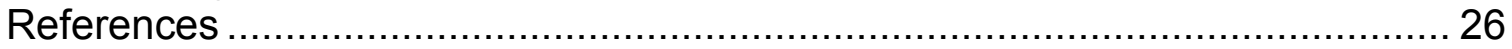

APPENDIX I: Geological Society of America Poster .................................... 31

APPENDIX II: Fugro Geophysical Report...................................................... 32

\section{Figures}

Figure 1. Location of study area and helicopter electromagnetic and magnetic survey for HEM surveys.

Figure 2. Helicopter-borne Resolve geophysical system similar to that used in the

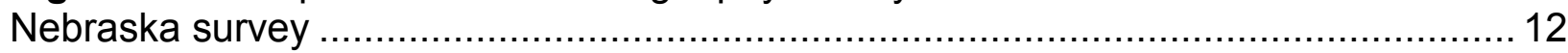

Figure 3. Depth of penetration or imaging as a function of frequency and Earth

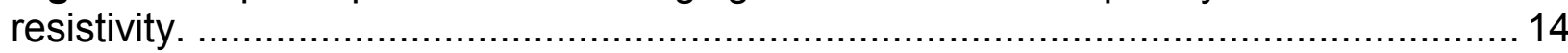

Figure 4. Screen shot of ArcMap plot of a GEOSOFT grid...................................... 23

Figure 5. Screen capture of Google Earth map for the HEM survey in the Sprague area,

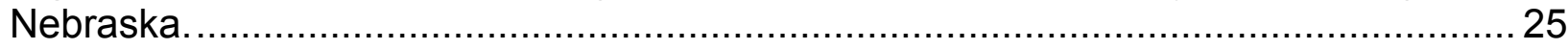

\section{Tables}

Table 1. Flight line description for 2009 HEM survey areas in eastern Nebraska. 
Table 2. Digital data organization and description for files and directories. .................. 9

Table 3. Flight line direction and spacing for each survey area. .............................. 10

Table 4. Frequencies and measurement sensitivities used for the HEM survey........... 13

Table 5. Fugro-specified data errors for the 2007 and 2009 HEM surveys.................. 17

\section{Conversion Factors, Datum, and Acronyms}

\section{SI to Inch/Pound}

\begin{tabular}{lcll}
\hline \multicolumn{1}{c}{ Multiply } & By & \multicolumn{1}{c}{ To obtain } \\
\hline meter $(\mathrm{m})$ & 3.281 & foot $(\mathrm{ft})$ & \\
kilometer $(\mathrm{km})$ & 0.6214 & mile $(\mathrm{mi})$ & \\
square kilometer $\left(\mathrm{km}^{2}\right)$ & 247.1 & acre & \\
nanotesla $(\mathrm{nT})$ & 1 & gamma & \\
\hline
\end{tabular}

Temperature in degrees Celsius $\left({ }^{\circ} \mathrm{C}\right)$ may be converted to degrees Fahrenheit $\left({ }^{\circ} \mathrm{F}\right)$ as follows:

${ }^{\circ} \mathrm{F}=\left(1.8 \times{ }^{\circ} \mathrm{C}\right)+32$.

Electrical conductivity is given in millisiemens per meter $(\mathrm{mS} / \mathrm{m})$ unless otherwise specified.

Electrical resistivity is given in ohm meters unless otherwise specified.

$1 \mathrm{mS} / \mathrm{m}=1000 /$ ( 1 ohm meter), thus $10 \mathrm{mS} / \mathrm{m}=100 \mathrm{ohm}$ meters.

Vertical coordinate information is referenced to the North American Vertical Datum of 1988 (NAVD 88) except as noted in text.

Horizontal coordinate information is referenced to the North American Datum of 1983, Universal

Transverse Mercator Zone 13 (NAD 83 UTM Zone 13N)" except as noted in text.

Airborne geophysical survey reference for GPS data is WGS84.

ACRONYMS USED IN THIS REPORT:
EM Electromagnetic
DTM Digital Terrain Model
GPS Global Positioning System
HEM Helicopter Electromagnetic
RTP Reduced-to-Pole
USGS U.S. Geological Survey
UTM Universal Transverse Mercator
IGRF International Geomagnetic Reference Field

ABBREVIATIONS USED IN THIS REPORT:

$\mathrm{Hz} \quad$ hertz

$\mathrm{kHz} \quad$ kilohertz

ppm part per million 


\section{Helicopter Electromagnetic and Magnetic Geophysical Survey Data, Swedeburg and Sprague Study Areas, Eastern Nebraska, May 2009}

By Bruce D. Smith, Jared D. Abraham, James C. Cannia, Burke J. Minsley, Lyndsay B. Ball, Gregory V. Steele, and Maria Deszcz-Pan

\section{Abstract}

This report is a release of digital data from a helicopter electromagnetic and magnetic survey conducted by Fugro Airborne Surveys in areas of eastern Nebraska as part of a joint hydrologic study by the Lower Platte North and Lower Platte South Natural Resources Districts, and the U.S. Geological Survey. The survey flight lines covered 1,418.6 line km (882 line mile). The survey was flown from April 22 to May 2, 2009. The objective of the contracted survey was to improve the understanding of the relation between surface water and groundwater systems critical to developing groundwater models used in management programs for water resources.

The electromagnetic equipment consisted of six different coil-pair orientations that measured resistivity at separate frequencies from about 400 hertz to about 140,000 hertz. The electromagnetic data were converted to georeferenced electrical resistivity grids and maps for each frequency that represent different approximate depths of investigation for each survey area. The electrical resistivity data were input into a numerical inversion to estimate resistivity variations with depth. In addition to the electromagnetic data, total field magnetic data and digital elevation data were collected. Data released in this report consist of flight line data, digital grids, digital databases of the inverted electrical resistivity with depth, and digital maps of the apparent resistivity and total magnetic field. The range of subsurface investigation is comparable to the depth of shallow aquifers. The survey areas, Swedeburg and Sprague, were chosen based on results from test flights in 2007 in eastern Nebraska and needs of local water managers. The geophysical and hydrologic information from U.S. Geological Survey 
studies are being used by resource managers to develop groundwater resource plans for the area.

\section{Introduction}

Airborne geophysical studies have been used effectively by the U.S. Geological Survey (USGS) in a variety of groundwater resource projects and programs (Smith and others, 2006; 2007). Electrical geophysical methods can be used to image the subsurface of the Earth using techniques similar to a medical CAT (computed axial tomography) scan of the human body (Won, 1990). A specific example is the helicopter electromagnetic (HEM) survey conducted for the USGS in the upper Missouri River Basin (Poplar, Montana) to study groundwater quality (Smith and others, 2006) in a similar hydrologic setting in parts of Nebraska. Based on the success of these and other groundwater studies using airborne geophysical methods, the USGS received funding from Nebraska state agencies to conduct subsurface airborne resistivity mapping over three pilot areas in eastern Nebraska in 2007 as described by Cannia and others (2007). This work was part of the Eastern Nebraska Water Resources Assessment (ENWRA), a cooperative effort involving ten local, state, and federal agencies to develop a three-dimensional geologic framework and water budget for the glaciated region, or eastern 1/5th of Nebraska (Korus and Divine, 2007). The results from the 2007 HEM project have been described and data released by Smith and others (2008a and 2008b). Following these successful surveys in eastern Nebraska, HEM surveys were flown in western Nebraska (Smith and others, 2009; 2010) and the results were used in groundwater models being developed by the North Platte and South Platte Natural Resources Districts (Abraham and others, 2009). Based in part on these successful applications of HEM for subsurface hydrostratigraphic mapping, the Lower Platte North and Lower Platte South Natural Resources Districts provided funding for new airborne surveys in 2009 to cover two new areas in eastern Nebraska. The results of the new surveys have been described by Divine and others (2009) in a poster presentation provided in Appendix I.

The airborne geophysical data described in this report were collected by Fugro Airborne Surveys Ltd. using a helicopter electromagnetic (HEM) system under contract 
to the NRDs. The contractor's report is included as a PDF file (Appendix II). The digital airborne geophysical data collected along flight lines were processed by the contractor to produce digital maps. Additional data processing was done by the USGS and supplemental maps were produced. These digital line data and maps are also included as part of the digital data release.

Eastern Nebraska contains 70 percent of the state's population but is most limited in terms of the state's groundwater supplies. Locally governed Natural Resources Districts (NRDs), charged with groundwater management in Nebraska, seek to improve their management plans in response to growing populations, hydrologic drought, and new conjunctive management laws. Detailed mapping and characterization is necessary to delineate aquifers, assess their degree of hydrologic connection with streams and other aquifers, and better predict water quality and quantity.

\section{Purpose and Scope}

This report presents HEM and magnetic digital maps and data that were collected for Lower Platte North and Lower Platte South Natural Resources District from April 22 to May 2, 2009 in cooperation with the U.S. Geological Survey, over two areas, Swedeburg and Sprague near Lincoln, Nebraska (fig. 1). Four reflight lines were flown as part of the Sprague survey over the adjacent Firth area previously flown in 2007. Survey coverage consisted of approximately 1,418.6 line km (882 line miles), including 97.7 line $\mathrm{km}$ (61 line miles) of tie lines. The breakdown of kilometers flown per area and the line direction and line spacing (where applicable), are given in table 1. 
Table 1. Flight line description for 2009 HEM survey areas in eastern Nebraska.

\begin{tabular}{|c|c|c|c|c|c|c|c|c|}
\hline Block & Area & $\begin{array}{l}\text { Traverse } \\
\text { azimuth }\end{array}$ & $\begin{array}{l}\text { Tie line } \\
\text { azimuth }\end{array}$ & $\begin{array}{c}\text { Traverse } \\
\text { line } \\
\text { spacing }\end{array}$ & $\begin{array}{c}\text { Tie line } \\
\text { spacing } \\
\text { (m) }\end{array}$ & $\begin{array}{l}\text { Traverse } \\
\text { line }(\mathrm{km})\end{array}$ & Tie line $(\mathrm{km})$ & Total $(\mathrm{km})$ \\
\hline 1 & Swedeburg & $315^{\circ}$ & $045^{\circ}$ & $280 \mathrm{~m}$ & 3000 & 272.7 & 34.3 & 307.0 \\
\hline 2 & Sprague & $090^{\circ}$ & $180^{\circ}$ & $280 \mathrm{~m}$ & various & $1,020.8$ & 63.4 & $1,084.2$ \\
\hline TOTAL & & & & & & $1,320.9$ & 97.7 & $1,418.6$ \\
\hline
\end{tabular}

The objective of the survey is to map subsurface hydrogeologic features in order to improve the understanding of the relation between surface water and groundwater systems critical to developing management programs for water resources. The airborne geophysical survey data can be used to map subsurface electrical and magnetic properties of the Earth that can be related to concealed geologic and hydrologic features. In particular, interpretation of the HEM data will be used to refine aquifer geometry for groundwater and geologic models in eastern Platte River Basin.

\section{Description of Study Areas}

Helicopter electromagnetic (HEM) surveys, flown in five selected areas of eastern Nebraska in 2007 and 2009 (fig. 1), mapped high-resistivity areas that correlate to and expand on known sand and gravel aquifers (Divine and others, 2009). To date, a total area of $680 \mathrm{~km}^{2}\left(263 \mathrm{mi}^{2}\right)$ has been surveyed using HEM. General flight line spacing was $270 \mathrm{~m}$ (890 ft). The primary purpose of the survey in 2007 was to test the applicability of HEM technology in identifying sand and gravel units underlying or within glacial deposits. Results from the $109 \mathrm{~km}^{2}\left(42 \mathrm{mi}^{2}\right)$ Firth pilot-study area indicated that 
expanding the study area to the west might allow better delineation of the interconnectivity of sand units with surface-water systems. Apparent resistivity maps from the Firth area showed two elongated bands of high-resistivity material that were interpreted as sand and gravel forming the shallowest portions and sides of a paleovalley aquifer. Evaluation of the depths of signal detection, which reached to $45 \mathrm{~m}$ (150 ft) in the deepest part of the sand and gravel unit, and the horizontal and vertical resolution were based on inverse modeling of vertical sections and resolution imaging, and not from the apparent resistivity maps. The data provide the aquifer's general trend and areal extent, though not its full depth.

At Firth, the 2009 survey extended the 2007 survey westward with the same flight line spacing and orientation and covered approximately $285 \mathrm{~km}^{2}\left(110 \mathrm{mi}^{2}\right)$. The objective of the 2009 survey was to delineate the western end of the paleovalley aquifer. The apparent resistivity data collected in overlapping flight blocks of the 2007 and 2009 surveys were congruent. Geologists expected the paleovalley aquifer to appear as in the first survey. However, data from the second block show highly resistive material is more widespread than in the original flight block. 


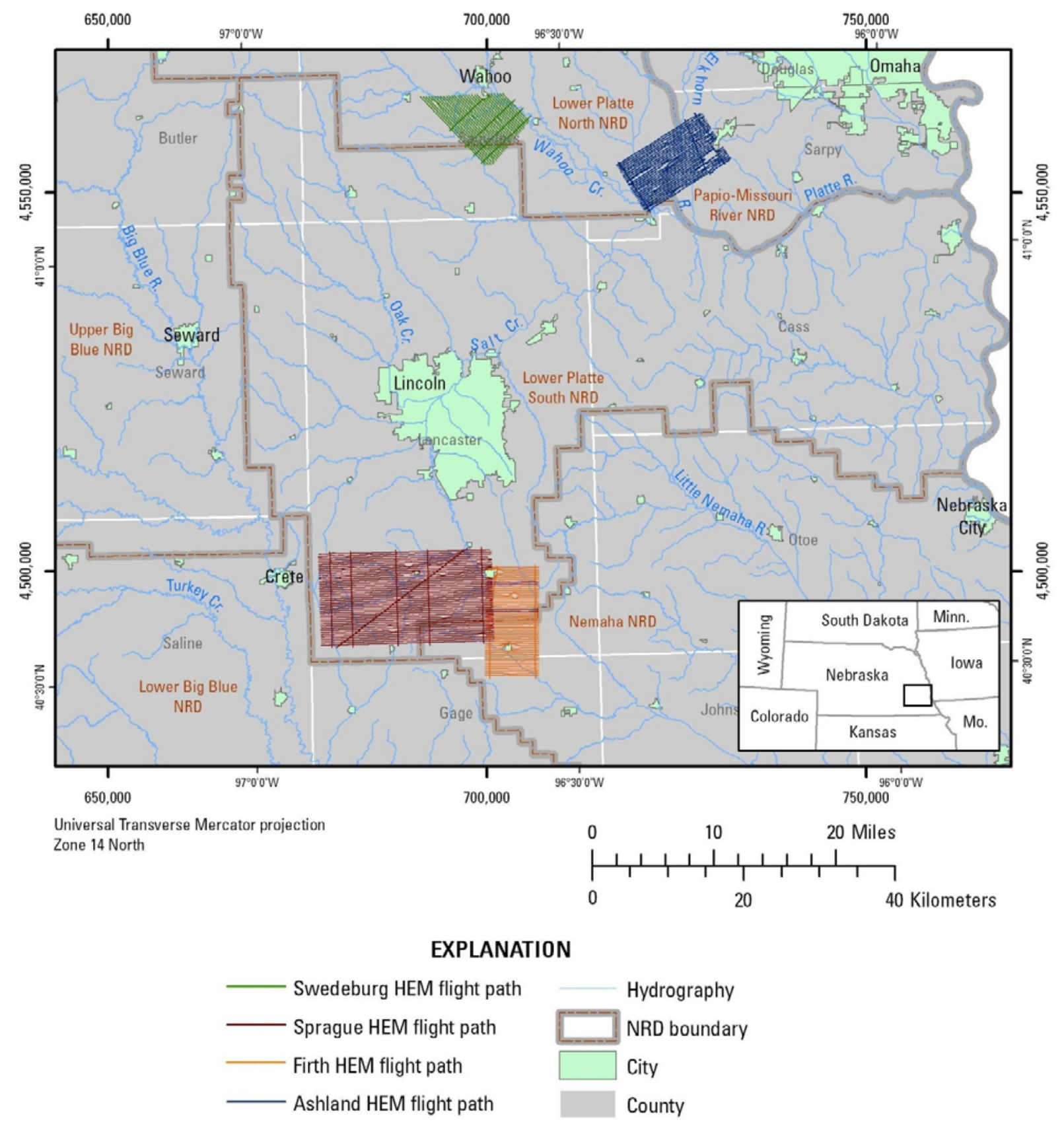

Figure 1. Location of study area and helicopter electromagnetic and magnetic survey for HEM surveys. Swedeburg area is Block 1 and has flight lines numbered 10xxx. Sprague area is Block 2 and has flight lines numbered 20xxx. Two repeat lines were flown in the Firth area that was flown in 2007 and have flight lines numbered 30010 and 30020. See also previous data release (Smith and others, 2008a). 


\section{Airborne Geophysical Survey Overview}

Management and allocation of water resources in Nebraska are based in part on understanding the relation between surface water and groundwater systems. To help understand these complex relations, the USGS conducted airborne resistivity and magnetic (frequency domain helicopter electromagnetic) surveys in eastern Nebraska in 2007 (Smith and others, 2008a) and western Nebraska in 2008 (Smith and others, 2009). The surveys in Western Nebraska were integrated with hydrologic studies (aquifer characteristics and modeling) and ground and borehole geophysical surveys to characterize and map the hydrogeologic framework in three dimensions. The preliminary results of these findings are described by Abraham and others (2010).

The airborne geophysical survey was structured in three main phases: (1) data acquisition and preliminary processing in the field, (2) final data processing conducted by the contractor (Fugro Airborne Ltd.) and by the USGS, and (3) interpretation of the processed data including conversion of flight line data to resistivity depth sections. This USGS Open-File Report and the report by the contractor given in Appendix II address the first two phases of the project. The interpretative phase will be ongoing and covered in separate publications and reports. A team of experts consisting of geophysicists, hydrologists, geologists, and groundwater managers is needed in evaluation of the processed data because interpretation requires an understanding of geophysical methods and hydrogeologic setting (Abraham and others, 2010).

\section{Geophysical Data Overview}

The digital data from the airborne survey were acquired and processed by the contractor, Fugro Airborne LTD, as described in Appendix II. The USGS did onsite quality control of the contractor's data acquisition. Onsite decisions were made 
concerning the location and orientation of flight lines. In-field processing of the data suggested that re-flights of portions of the Firth area flown in 2007 was warranted to facilitate leveling of data from the two surveys to each other. Two lines from the 2007 survey of Firth were repeated in the 2010 survey (fig. 1). The USGS reviewed the FUGRO data post processing and report for final acceptance. In addition the USGS reprocessed the electromagnetic data to meet the specific hydrogeologic requirements of this project. Both the contractor and USGS digital data are included in the present data release. Table 2 contains links to the digital data and a brief description of the files and directories. 
Table 2. Digital data organization and description for files and directories.

\begin{tabular}{|c|c|}
\hline Folder & Description \\
\hline METADATA & Metadata description of digital data by survey block \\
\hline GIS SURVEY & $\begin{array}{l}\text { Geographic information consisting of digital raster graphics } \\
\text { (DRG) and survey flight lines (FLIGHT_LINES). The FLIGHT } \\
\text { LINE folder contains subdirectories of autocad files (CAD_DXF) } \\
\text { and shape files (lineSHP). }\end{array}$ \\
\hline$\underline{\text { GRIDS }}$ & $\begin{array}{l}\text { Grids of the electromagnetic and magnetic field data for the } \\
\text { horizontal coplanar coil pairs are in this folder. The grids are in } \\
\text { Geosoft OASIS MONTAJ (http://www.geosoft.com/) format, a } \\
\text { 'standard' of the geophysical industry used in many map display. }\end{array}$ \\
\hline LINEDATA & $\begin{array}{l}\text { Flight line data are in ascii standard (XYZ) format that can be } \\
\text { read into Geosoft OASIS MONTAJ (http://www.geosoft.com/) } \\
\text { databases.The readme file in this folder contains a description of } \\
\text { the channels of the digital line data. }\end{array}$ \\
\hline$\underline{\mathrm{GIS}}$ & $\begin{array}{l}\text { This folder contains shape and autocad format files of flight lines } \\
\text { and outlines of survey area. Also .tif files are given for the } \\
\text { geographic base maps of the survey areas }\end{array}$ \\
\hline$\underline{\text { PLOTS }}$ & $\begin{array}{l}\text { Subfolder GEOTIFF (UTM13N. NAD83 projected “.tif" files) of the } \\
\text { grids are in this subfolder. Subfolder KMZ This folder contains } \\
\text { plots of flight lines and apparent resistivity maps in key hole } \\
\text { markup language (extension kmz). These files will plot directly in } \\
\text { GOOGLE EARTH (see report for details) }\end{array}$ \\
\hline REPORT & $\begin{array}{l}\text { Folder contains this report, appendix I (poster presented at the } \\
\text { Geological Society of America } 2009 \text { annual meeting), and } \\
\text { appendix II (contractor's report). }\end{array}$ \\
\hline DEPTHSEC & $\begin{array}{l}\text { Folder contains the databases of the inverted depth section for } \\
\text { the } 2007 \text { and } 2009 \text { surveys in western Nebraska }\end{array}$ \\
\hline
\end{tabular}




\section{Helicopter Electromagnetic and Magnetic Survey}

\section{Method and Measurements}

Kirsh (2006) and Rubin and Hubbard (2005) provide overviews of geophysical principles and applications to groundwater studies. Airborne geophysical surveys are usually made along regularly spaced flight lines within specified survey areas (fig. 1 and 3). Flight lines can be as close as $50 \mathrm{~m}$, though closer spacing is possible in special circumstances. The USGS has generally flown HEM surveys with 200-400-m spacing (1/8 to 1/4 mile: Smith and others, 2007), though flight lines with $800 \mathrm{~m}$ separation have been used to map regional structures in a carbonate aquifer setting (Smith and others, 2008c). Table 3 gives the flight line specifications for each survey area.

Table 3. Flight line direction and spacing for each survey area. Flight lines are numbered according to block. For example, block 1 flight lines are numbered 10010 , 10020 , etc.

\begin{tabular}{|l|c|c|c|c|c|c|c|c|}
\hline Block & Area & $\begin{array}{c}\text { Traverse } \\
\text { azimuth }\end{array}$ & $\begin{array}{c}\text { Tie line } \\
\text { azimuth }\end{array}$ & $\begin{array}{c}\text { Traverse } \\
\text { line } \\
\text { spacing }\end{array}$ & $\begin{array}{c}\text { Tie line } \\
\text { spacing } \\
(\mathrm{m})\end{array}$ & $\begin{array}{c}\text { Traverse } \\
\text { line }(\mathrm{km})\end{array}$ & $\begin{array}{c}\text { Tie line } \\
(\mathrm{km})\end{array}$ & $\begin{array}{c}\text { Total } \\
(\mathrm{km})\end{array}$ \\
\hline 1 & Swedeburg & $315^{\circ}$ & $045^{\circ}$ & $280 \mathrm{~m}$ & 3000 & 272.7 & 34.3 & 307.0 \\
\hline 2 & Sprague & $090^{\circ}$ & $180^{\circ}$ & $280 \mathrm{~m}$ & various & 1020.8 & 63.4 & 1084.2 \\
\hline 3 & $\begin{array}{l}\text { Reflight of } \\
\text { Firth lines }\end{array}$ & $090^{\circ}$ & & & & 27.4 & & 27.4 \\
\hline TOTAL & & & & & & 1320.9 & 97.7 & 1418.6 \\
\hline
\end{tabular}

The main part of the geophysical system is housed in a cylindrical tube or "bird" that is towed beneath the helicopter. In the system flown by Fugro Airborne Ltd., all of the measurement systems in the bird are transmitted by a cable to a processing and digital recording system in the helicopter. Electromagnetic (EM) and magnetic field 
geophysical data measurements are made approximately every three meters along the flight line. Figure 2 shows the instrumentation used for HEM surveys similar to that used for this survey.

\section{Bectromagnetic Measurements}

The principles of HEM methods are summarized by Siemon (2006) and Paine and Minty (2005). The RESOLVE ${ }^{\odot}$ HEM system flown by Fugro Airborne Ltd. is described in detail in Appendix II. The EM measurements are made using six coil pairs that measure EM signals at separate frequencies from about $400 \mathrm{~Hz}$ to about 140,000 $\mathrm{Hz}(140 \mathrm{kHz})$. Five of the coil pairs were oriented in a horizontal, coplanar position and one of the coil pairs was oriented in a vertical, coaxial position. The specific frequencies, separation, orientation of the coil pairs are given in table 4 . 




Figure 2. Helicopter-borne Resolve geophysical system similar that used in the Nebraska survey: Electromagnetic, magnetic, GPS, and laser altimeter sensors are housed in a "bird", a cigar-shaped 9-m long tube, which is kept at about 30-40 m above ground. 
Table 4. Frequencies and measurement sensitivities used for the HEM survey. The coil pair separation is 7.9 meters for all except for the $3,300 \mathrm{~Hz}$ coil-pair which is 9.0 meters.

\begin{tabular}{|c|c|c|c|}
\hline Coil configuration & $\begin{array}{c}\text { Nominal } \\
\text { frequency hertz }\end{array}$ & $\begin{array}{c}\text { Actual } \\
\text { frequency hertz }\end{array}$ & $\begin{array}{c}\text { Sensitivity parts per } \\
\text { million }\end{array}$ \\
\hline Coplanar & 400 & 395 & 0.12 \\
\hline Coplanar & 1,800 & 1,822 & 0.12 \\
\hline Coaxial & 3,300 & 3,262 & 0.12 \\
\hline Coplanar & 8,200 & 8,199 & 0.24 \\
\hline Coplanar & 40,000 & 38,760 & 0.60 \\
\hline Coplanar & 140,000 & 128,755 & \\
\hline
\end{tabular}

The EM measurements made approximately every three meters (ten feet) along flight lines are reduced to apparent resistivity values as described in the contractor's report (Appendix II). One important consideration of the HEM Earth subsurface imaging is that the depth of imaging is dependent on the frequency and resistivity of the Earth. One estimate of the depth of exploration (depth of mapping) for the frequencies used in the RESOLVE ${ }^{\odot}$ system is shown in figure 3 . In this figure, the depth of exploration is defined as 0.5 of the skin depth (point with the Earth at which a plane electromagnetic wave has attenuated to 37 percent of the initial amplitude). The depths of exploration estimates shown in figure 3 are conservative since one skin depth generally is considered to be the depth limit of HEM measurements (Fraser, 1978). Generally, at the highest frequency, depths of exploration are just a few meters. At the lowest frequency, $400 \mathrm{~Hz}$, the depth of exploration may be on the order of $80 \mathrm{~m}$ in the electrically resistive terrain. Varying depths of investigation at various frequencies for HEM resistivity 


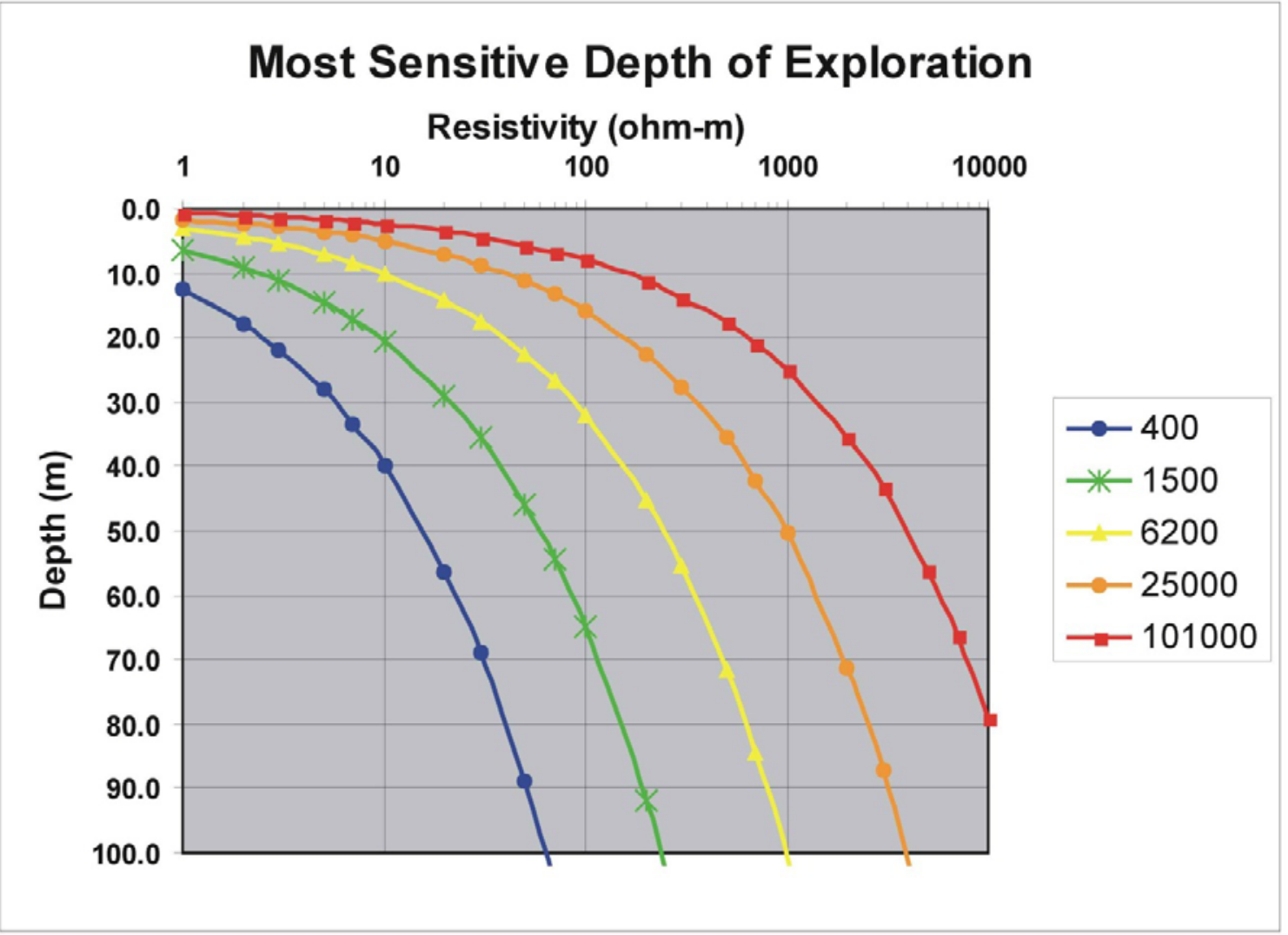

Figure 3. Depth of penetration or imaging as a function of frequency and Earth resistivity for the RESOLVE ${ }^{\odot}$ system (Hodges, Fugro Airborne, 2004, written communication).

measurements is the basic principle that allows depth images to be constructed. Additional discussion of the depth of investigation can be found in the following section on EM data inversion.

The EM signals are recorded for each frequency as in-phase and quadrature (out-of-phase) as referenced to the transmitted signal. These signals are postprocessed to apparent resistivity for each frequency and a corresponding apparent depth as described in Appendix II and by Fraser (1978). The apparent resistivity is, as the name implies, not the intrinsic electrical resistivity of the Earth but a value estimated based on assumptions of the measurement and of a homogeneous Earth (Fraser, 1978). Estimates of the intrinsic resistivity are obtained through a variety of imaging methods that are described by Siemon (2006) and Hodges (2004). The differential resistivity and depth transformation (Huang and Fraser, 1996) is one simple depth imaging method that has proven effective for HEM survey data (Smith and others, 2003). Both the 
apparent resistivity and differential data are given in the digital line data files (see readme file in LINEDATA folder).

An important part of the data processing is leveling the EM signals for system drift and calibrations. The specific steps used in the data processing are described in Appendix II. The digital line data gives the raw in-phase and quadrature data and the processed data from which the apparent resisitivites are computed. The final leveled data is also provided. These data are included in the data base in case the original data is used for reprocessing.

\section{Total Magnetic Feld Measurements}

The HEM system uses a total magnetic sensor (see Appendix II for details) that measures the Earth's total field to an accuracy of 0.01 nanoTesla (nT). The magnetic field consists of the Earth's main magnetic field and the local magnetic field due to sources within the crust and ferromagnetic metallic sources at the surface. The total field measurements are influenced by short term variations in the magnetic field which are independent of local sources and are caused mainly by solar activity. A total magnetic field base station, set up by the contractor near the base of operations, is used to record these short term variations in the Earth's total magnetic field which is subtracted from the measurements made during the survey. Sharma (2002) describes the basic principles of the main magnetic field removal.

The contractor processed the total magnetic field to remove the spatial variation from the Earth's main magnetic field. This spatial variation is defined by the International Geomagnetic Reference Field (IGRF). The removal process is described in more detail in the contractor's report in Appendix II.

\section{Ancillary Measurements}

The airborne electromagnetic system also monitors $60 \mathrm{~Hz}$ signals in coaxial and coplanar coil configurations. The data are given as CXPL CPPL channels in the line database (LINEDATA). The data are given as arbitrary voltage levels, which generally increase over power lines. The expression of power lines is quite variable due to a number of factors such as the size of the line, how well it is "grounded", and the 
electrical resistivity of the Earth. In general the infrastructure around urban development, transmission towers, and along major roads has a higher cultural noise level resulting in high $60 \mathrm{~Hz}$ signals.

Positioning measurements of the bird and the helicopter are critical in processing and making accurate maps. Location data from the GPS system in both the bird and helicopter are given in the files in the LINEDATA folder. Elevation data from the laser altimeter on the bird as well as the radar and barometric altimeters on the helicopter are given in the LINEDATA files. An important aspect of the contractor's data processing is the elevation data are given in the WGS84 Spheroid and have not been reduced to an ellipsoid. The contractor's report explains that additional processing needed to do this data reduction was not part of the NRD contract.

\section{Inversion of Bectromagnetic Data}

Abraham and others (2009) describes the application of inversion of HEM data to obtain resistivity - depth estimates along flight lines that then can be interpreted in terms of hydrologic model parameters. The multifrequency HEM data are inverted using the code EM1DFM (Farquharson, 2000; Farquharson and others, 2003). This is a 1-D nonlinear least-squares algorithm that recovers the distribution of electrical conductivity (reciprocal of resistivity) with depth beneath each sounding. The inversion algorithm minimizes an objective function $(\Phi)$ that is a combined measure of data misfit $\left(\phi_{d}\right)$ and model norm $\left(\phi_{m}\right)$ given by

$$
\Phi=\phi_{d}+\beta \phi_{m} .
$$

Inversion of HEM data is ill-posed and nonunique; that is, there are many resistivity models that are consistent with the measured data, and some form of regularization is needed to stabilize the inverse problem. Regularization is introduced through the model norm, which favors specific properties in the inverted model such as

proximity to a reference model or smoothness. The relative importance of fitting the data compared to controlling the model through regularization is controlled by a tradeoff parameter, $\boldsymbol{\beta}$. Details on how $\boldsymbol{\beta}$ was chosen for the inversions in this study are discussed below. 
The data misfit component of the objective function describes how well the observed data matches the data predicted by the inverted resistivity model. Specifically, it is defined as the L2-norm of the difference between observed and predicted data, normalized by the data error, for each frequency.

$$
\boldsymbol{\phi}_{d}=\left\|W_{d}\left(d^{\text {obs }}-d^{\text {pred }}\right)\right\|^{2}
$$

The data weighting operator, $W_{d}$, is a diagonal matrix with entries $\sigma_{f}^{-1}$, where $\sigma_{f}$ is the standard deviation of the noise for each frequency. Specification of the data errors is an important, but often overlooked, aspect of the inverse problem. Set too low, the algorithm will tend to fit noise in the data and result in models with too much structure. Set too high, the algorithm can easily fit the data with many models, and the resulting models are strongly controlled by the regularization term. Data errors used for inversion with the 2007 and 2009 datasets were taken from the Fugro report for each survey, and are summarized in table 5 .

Table 5. Fugro-specified data errors for the 2007 and 2009 HEM surveys.

\begin{tabular}{|c|c|c|c|}
\hline \multicolumn{2}{|c|}{2007} & \multicolumn{2}{|c|}{2009} \\
\hline Frequency (Hz) & $\begin{array}{c}\text { Data error (In- } \\
\text { phase and } \\
\text { quadrature, ppm) }\end{array}$ & Frequency (Hz) & $\begin{array}{c}\text { Data error (In- } \\
\text { phase and } \\
\text { quadrature, ppm) }\end{array}$ \\
\hline 380 & 5 & 395 & 10 \\
\hline 1,760 & 10 & 1,822 & 10 \\
\hline 3,270 & 10 & 3,262 & 10 \\
\hline 6,520 & 10 & 8,199 & 20 \\
\hline 26,640 & 20 & 38,760 & 40 \\
\hline $116,400 \mathrm{~Hz}$ & 40 & 128,755 & 50 \\
\hline
\end{tabular}


The model norm component of the objective function is a combined measure of proximity to a reference model and smoothness.

$$
\boldsymbol{\phi}_{m}=\boldsymbol{\alpha}_{s}\left\|m-m^{r e f}\right\|^{2}+\boldsymbol{\alpha}_{z}\|\nabla m\|^{2}
$$

The scaling terms $\alpha_{s}$ and $\boldsymbol{\alpha}_{z}$ control the relative importance given to proximity to the reference model and model smoothness, respectively. Because $\beta$ scales both $\boldsymbol{\alpha}_{s}$ and $\boldsymbol{\alpha}_{z}$, it is only important to specify the relative weight of these latter terms, which is often simplified by setting one of them to 1 .

\section{Testing to Determine Optimal Inversion Parameters}

Before inverting the HEM datasets, a series of parameter tests were carried out on a test line extracted from the dataset to determine the optimal starting model, reference model, and tradeoff parameters $\boldsymbol{\beta}, \boldsymbol{\alpha}_{s}$, and $\boldsymbol{\alpha}_{z}$. All of the inversions were parameterized with a 25-layer model, where the depth to the top of the underlying halfspace was $125 \mathrm{~m}$. The thicknesses of each layer, automatically assigned by EM1DFM, are summarized in Table 6.

Table 6. Layer thicknesses used for HEM inversions.

\begin{tabular}{|l|l|}
\hline Layer & Thickness \\
\hline 1 & 0.860682 \\
\hline 2 & 0.976045 \\
\hline 3 & 1.10687 \\
\hline 4 & 1.25523 \\
\hline 5 & 1.42348 \\
\hline 6 & 1.61427 \\
\hline 7 & 1.83064 \\
\hline 8 & 2.07602 \\
\hline 9 & 2.35428 \\
\hline 10 & 2.66984 \\
\hline 11 & 3.02769 \\
\hline 12 & 3.43351 \\
\hline
\end{tabular}

\begin{tabular}{|l|l|}
\hline 13 & 3.89372 \\
\hline 14 & 4.41562 \\
\hline 15 & 5.00747 \\
\hline 16 & 5.67866 \\
\hline 17 & 6.43980 \\
\hline 18 & 7.30297 \\
\hline 19 & 8.28183 \\
\hline 20 & 9.39189 \\
\hline 21 & 10.6507 \\
\hline 22 & 12.0783 \\
\hline 23 & 13.6973 \\
\hline 24 & 15.5332 \\
\hline 25 & half-space \\
\hline
\end{tabular}


The starting model was selected by computing the best-fitting half-space for each sounding along the test line. The median value was approximately $0.0333 \mathrm{~S} \cdot \mathrm{m}^{-1}(30$ $\Omega \cdot \mathrm{m}$ ), which is used for the starting model and base reference model for all subsequent runs.

In order to select the tradeoff parameters, multiple inversions were run using all

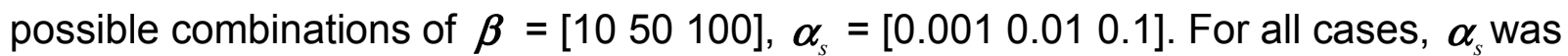
fixed at 1.0 because it is only the relative value of this parameter with respect to $\alpha_{s}$ that is important. In addition to the inversion runs with fixed values of $\boldsymbol{\beta}$, an additional set of inversions were run using the same three values for $\boldsymbol{\alpha}_{s}$, but with the generalized crossvalidation (GCV) criterion (Farquharson, 2000; Haber and Oldenburg, 2000) for automatically selecting an optimal value for $\beta$ at each sounding along the line. Use of the GCV method for selecting $\beta$ is more robust, but can sometimes result in significant model artifacts when there is unaccounted for noise in the data.

Based on the inverted models using the above parameters, it was determined that the GCV method of automatically selecting $\beta$ produced the best results along the entire test line. The GCV method was particularly useful in selecting different values of $\beta$ that were best suited to sections of the test line with different subsurface structural properties (for example, over deep, resistive channels). The best value for $\boldsymbol{\alpha}_{s}$ was chosen as 0.005 , based on observation of the test inversions using $\alpha_{s}=0.001$ and 0.01. A summary of the complete set of inversion parameters used in EM1DFM is shown in table 7.

Table 7. Summary inversion parameters for use in EM1DFM.

\begin{tabular}{|l|l|}
\hline Model type & Conductivity only \\
\hline Starting conductivity model & 25 layers, $125 \mathrm{~m}$ to top of halfspace, $30 \Omega \cdot \mathrm{m}$ \\
\hline Base reference model & $30 \Omega \cdot \mathrm{m}$ \\
\hline Tradeoff parameter method & $\mathrm{GCV}$ \\
\hline Model norm components & $\mathrm{s}=0.005, \mathrm{z}=1$ \\
\hline
\end{tabular}




\section{Model Assessment Using the Depth of Investigation (DO) Metric}

The depth of investigation (DOI) metric (Oldenburg and $\mathrm{Li}, 1999$ ) is a valuable tool for evaluating the approximate depth in an inverted model to which the data are sensitive. The DOI metric is defined as the difference between two models inverted with different reference models, divided by the difference in reference models

$$
D O I=\frac{m^{1}-m^{2}}{m_{0}^{1}-m_{0}^{2}} .
$$

Because EM1DFM solves for log-conductivity values, we use $m=\log _{10} \sigma$ to compute the DOI metric. Where the inverted models, $m^{1}$ and $m^{2}$, are strongly determined by the data (that is, shallow regions with greater sensitivity), $m^{1} \approx m^{2}$ and $D O I \rightarrow 0$. At depth where the data are not sensitive to the model parameters, regularization in the inverse problem forces the inverted model to be close to the reference model so that $m^{1} \approx m_{0}^{1}$, $m^{2} \approx m_{0}^{2}$, and $D O I \rightarrow 1$. Small values of the DOI metric, therefore, represent regions in the model that are most strongly determined by the data.

To compute the $\mathrm{DOI}$ metric, additional inversions are run with reference models $m_{0}^{1}=6 \Omega \cdot \mathrm{m}$ and $m_{0}^{2}=150 \Omega \cdot \mathrm{m}$, which are scaled by a factor of 5 from the base reference model of $30 \Omega \cdot \mathrm{m}$. A cutoff value for the DOI metric is specified such that portions of the inverted models with DOI values greater than the cutoff are strongly influenced by the reference model. In this study, we use $D O I_{\text {cutoff }}=0.2$.

The DOI metric is a useful tool when displaying the final inverted images because it provides a means for displaying areas of confidence in the model. In many instances, geophysical images are presented without any measure of where the models are determined by the data and where they are simply a reflection of the reference model. A simple approach is to completely blank-out regions in the model where $D O I>D O I_{\text {cutoff }}$, preserving only the parts of the model that are controlled by the measured data. 


\section{Digital Data}

Digital data are given in the folders described in table 2. The following describes the digital data in each subfolder.

\section{Metadata}

The METADATA folder contains files that describe geophysical survey blocks (fig. 1). These survey blocks are the boundaries for line data, digital grids, and plots. The metadata also describe the projection used for all of the digital plots which is North American Datum of 1983 (NAD83) Universe Transverse Mercator zone 14 north (UTM14N) in meters.

\section{GIS Data}

The GIS folder contains various files that may be useful in map preparation. The flight line location files are in dxf (AUTOCAD) and as ESRI shape files (.shp and ancillary files). Outlines for each survey area are given as .shp files.

\section{Grids}

Flight line data are interpolated onto a regular grid (gridded) to produce map plots. One of the challenges of gridding airborne geophysical data is that the spacing between flight lines is much greater than the sampling along the line (a few meters). Specialized gridding methods have been developed to deal with this aspect of processing airborne geophysical data (Smith and O'Connell, 2005). The contractor has used a modified Akima spline method (Appendix II) to construct grids of the airborne geophysical data. The contractor grids are given in the GRIDS folder in the FUGRO subfolder. These grids have not been modified. The nomenclature for the grid names is given in the readme.txt file.

An alternate gridding method is the minimum curvature method implemented by Webring (1981) for geophysical airborne data. This gridding method is used in the GEOSOFT OASIS MONTAJ program (Geosoft user's manual, 7.2, 2010; http://www.geosoft.com/resources/papers/pdfs/topicsingriddingworkshop.pdf). We have 
used this algorithm to produce grids from selected channels of the flight line data. These grids can be found in the subfolder USGS. The grid cell size was $75 \mathrm{~m}$. File naming convention is given in the readme.txt file. The USGS grids also include the magnetic data, digital elevation, and powerline monitor data. These grids have 75 meter cell size. The grids can be viewed in free software distributed by GEOSOFT (http://www.geosoft.com/downloads).

Plug-ins for various mapping software packages can also be found on the GEOSOFT web site. Plots produced from the grid files are described below.

The grids can be imported into ESRI ArcMap applications with a plug-in provided by GEOSOFT

(http://www.geosoft.com/resources/releasenotes/plugins/arcGISplugin.asp). A sample display of one such plot in ArcMap is shown in figure 4. Color scale bars can be imported to match those of the geoTIFF maps. The grids may need to be given specific projection information (NAD83 UTM13N) depending on the base maps that are used.

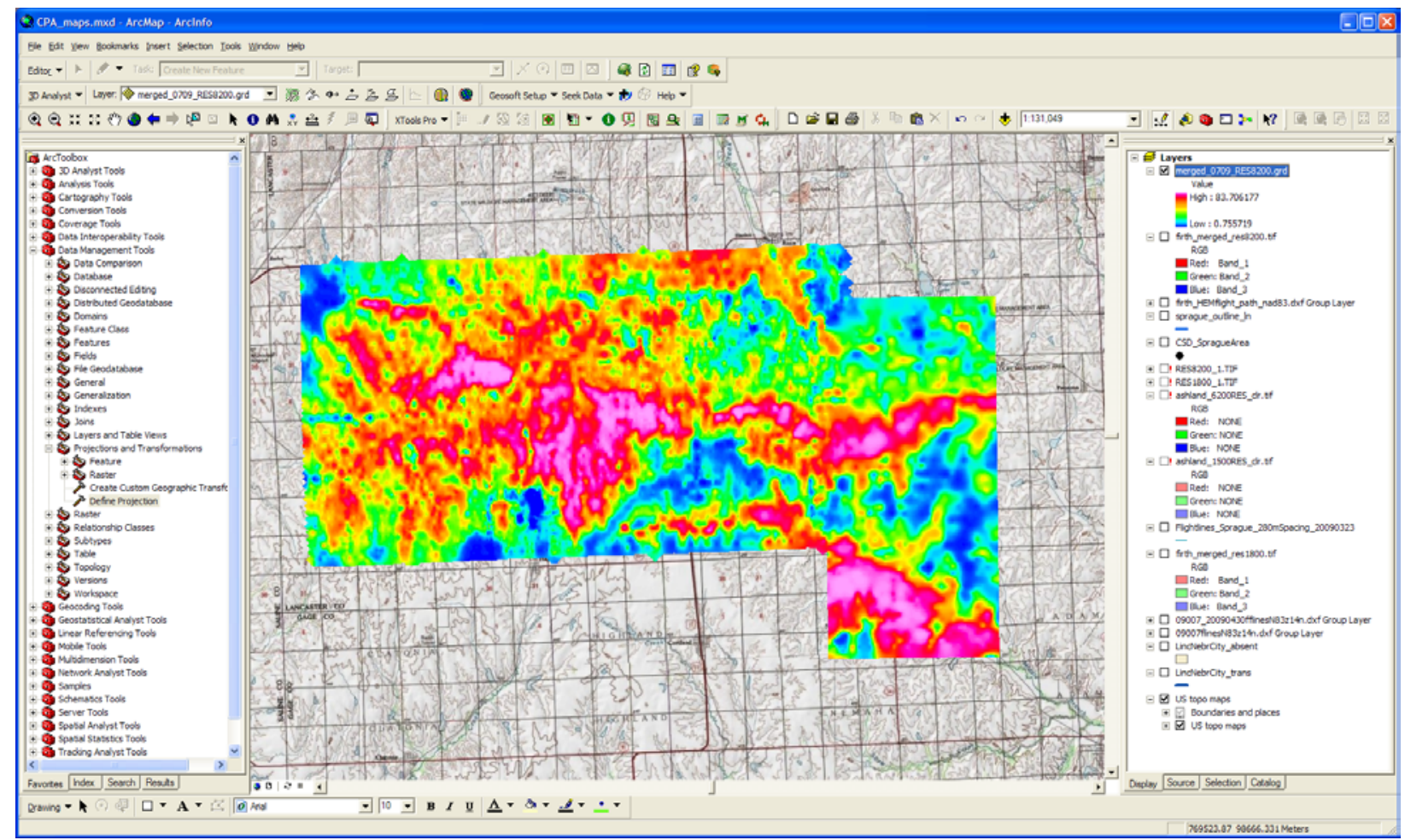


Figure 4. Screen shot of ArcMap plot of a GEOSOFT grid for the 2009 Swedeburge-Firth area. Note the GEOSOFT plugin is displayed in the toolbar. The background topographic relief map is displayed using data added by internet servers. The toolbox display in the lower left shows data management tools that might be needed to define the projection of the grid.

\section{Plots}

The USGS has produced plots (PLOTS folder) of the gridded data described above as PDF files (PDF folder) and georeferenced tiff format (GEOTIFF folder) files. The projection used for the geotiff plots is the same as the grids, NAD83 UTM13N. The plot files have been produced with a color scale common to all frequencies for each survey area. Thus the colors for apparent resistivity maps can be directly compared between frequencies. Generally the apparent resistivity is higher by about $75 \mathrm{ohm}$ meters for the North Platte River area so a color scale with a slightly different range has been used than for the Lodgepole Creek area. The color scale gives high resistivity as warm colors (reds) and low resistivity as cool colors (blues).

\section{Digital Flight line Data}

The flight line data for each area are given in the folder LINEDATA. The files are given in ascii format with column headings as described in the readme file. The contractors report in APPENDIX II also describes the digital flight line data.

\section{Keyhole Markup Language (KML) Files}

$\mathrm{KML}$ is a file format used to display geographic data in an Earth browser such as Google Earth, Google Maps, and Google Maps for mobile. According to Wikipedia (http://en.wikipedia.org/wiki/Kml) KML was developed for use with Google Earth, which was originally named Keyhole Earth Viewer. It was created by Keyhole, Inc., which was acquired by Google in 2004. The name "Keyhole" is a homage to the $\mathrm{KH}$ reconnaissance satellites, the original eye-in-the-sky military reconnaissance system first launched in 1976. Files in this report are compressed or "zipped" KML files with the extension .kmz. They import directly into Google Earth. 
Presentation of HEM data at an early public meeting on HEM surveys showed that there was interest in being able to show geophysical flight lines and data in Google Earth (GE) using kmz files. Consequently a set of files in this format have been included in this report. In the year that has passed since that meeting there has been increasing interest in use of GE as a platform for display of earth science maps and data. A special session at the 2009 American Geophysical Union and the keynote address of the meeting (Frontiers of Geophysics Lecture: The Spread of Scientific Knowledge From the Royal Society to Google Earth and Beyond; Presented by: Michael Jones, Chief Technical Officer, Google Earth; http://www.agu.org/webcast/fm08/) discussed use of GE in earth and planetary sciences.

A users guide to GE can be found at the following hyperlink: (http://earth.google.com/int//en/userguide/v5/). The display of flight lines and data can be accomplished by clicking the files in the KMZ folder (if a link has been established for this file type) or by opening the .kmz file in GE. A sample image of the GE displays is shown for a sample area near Sidney, Nebraska in figure 5. 


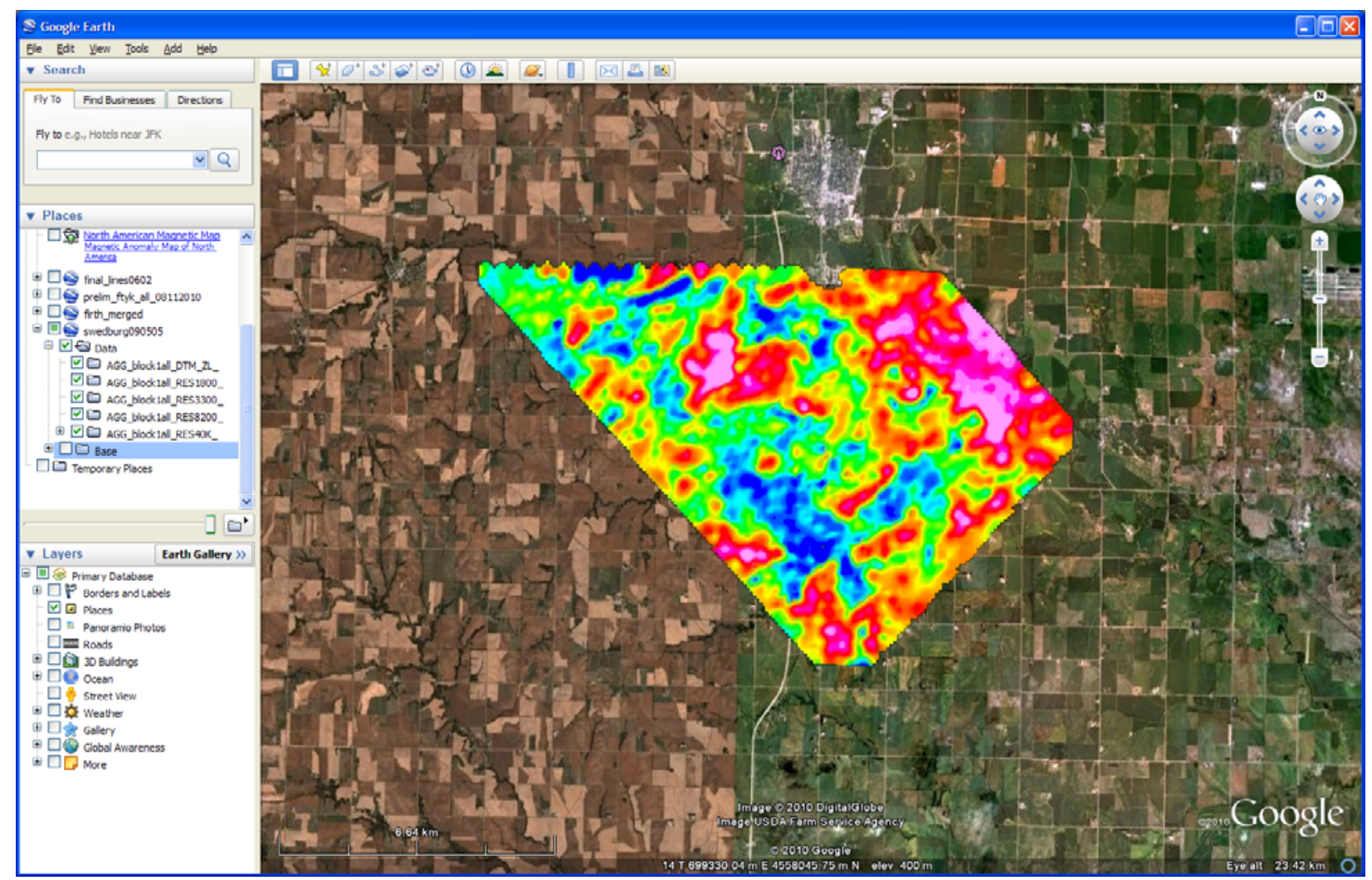

Figure 5. Screen capture of Google Earth $®$ map for the HEM survey in the Sprague area, Nebraska. The data shown is the apparent resistivity map at $40,000 \mathrm{~Hz}$. Note in the panel on the left of the display, various layers can be turned on and off to show other frequencies and the flight path.

\section{Resistivity Depth Section Database}

The resistivity as a function of depth along the flight lines as determined from the depth imaging or inversion described above is given in the depthsec folder (table 2). One important aspect of the plotting of depth sections is plotting the corresponding elevations. As described in the Fugro report, the elevation data from the GPS and laser altimeter have not been projected in an orthometric fashion. The laser altimeter gives the distance about earth's surface only (see contractor's report, Appendix II).

Elevation data are provided relative to two datums. In the electromagnetic and magnetic databases, radar altimeter values were subtracted from the differentially corrected and despiked GPS values to provide land-surface elevations above the World Geodetic System of 1984 (WGS84) ellipsoid along survey lines (Fugro Airborne 
Surveys Ltd., 2008). These elevations are available only along survey lines and are not consistent with the datum being used by water-resource managers and groundwater modelers in the Nebraska panhandle. To facilitate comparison of the inverted resistivity profiles to other data, such as borehole lithology and geophysical logs, and to make future interpretations more immediately useful for local studies, elevations in the inverted resistivity databases have been sampled from pre-existing digital elevation models. Ten-meter resolution digital elevation models produced in cooperation between the U.S. Geological Survey and the Nebraska Department of Natural Resources (accessed April 2010 at URL: http://www.dnr.state.ne.us/databank/dbindex.htm/) were converted to the NAD83 projection and provide elevations in meters relative to the National Geodetic Vertical Datum of 1929 (NGVD29).

It is critical in using the depth data given in the databases to check projections or use digital elevations from other models being used.

\section{Acknowledgments}

The authors would like to thank Dana Divine, ENWRA Project Coordinator and Richard Ehrman of the Lower Platte South Natural Resources District for their guidance and efforts. The Lower Platte North Natural Resources District provided funding for the Sprague survey area. The authors also thank Larry Angle for his technical efforts in the Swedeburg area and the Lower Platte North Natural Resources District for funding this effort. Michelle Johnson provided USGS GIS support through planning and data release parts of the project The authors would also like to thank the following personnel of Fugro Airborne Surveys, for their insight and technical support with organizing, collecting, processing and interpreting the HEM data: Greg Hodges, Geophysicist, Dima Amine, Contract Liaison, Lesley Minty, Project Manager, Amanda Heydorn, Field Geophysicist/Crew Leader, Chris Tucker Pilot (Great Slave Helicopters Ltd.), Russell Imrie, Interpretation Geophysicist, Richardo White, Geophysical Data Processor, Lyn Vanderstarren, drafting and geophysical flight line layouts.

\section{References}


Abraham, J.D., Bedrosian, P.A., Ball, L.B., Cannia, J.C., Minsley, B.J., Peterson, S.M., and Smith, B.D., 2009, Quantitative hydrogeological framework interpretations from modeling helicopter electromagnetic survey data, Nebraska panhandle: American Geophysical Union Annual Meeting, San Francisco, 1 p.

Abraham, J.D., Cannia, J.C., Peterson, S.M., Smith, B.D., Minsley, B.J., and Bedrosian, P.A., 2010, Using airborne geophysical surveys to improve groundwater resource management models: Proceedings Symposium on the Application of Geophysics to Engineering and Environmental Problems, Environmental and Engineering Geophysical Society, $10 \mathrm{p}$.

Cannia, J.C., Abraham, J.A., Smith, B.D., Steele, G.V., and Korus, J.T., 2007, Preliminary results of hydrogeological framework studies of surface water ground water systems in eastern Nebraska using airborne and ground geophysics: Geological Society of America Abstracts with Programs, v. 39, no. 6 , p. 162.

Divine, D.P. Steele, G.V., Smith, B.D., Ehrman, R.L., and Korus, J.T., 2009, Preliminary Results from helicopter electromagnetic surveys over a paleovalley aquifer in eastern Nebraska: Geological Society of America Abstracts with Programs, v. 41, no. 7, p. 286.

Farquharson, C.G., 2000, Background for program "EM1DFM": University of British Columbia Geophysical Inversion Facility, Vancouver, Canada. 20 p., accessed August, 2010, at: http://www.eos.ubc.ca/ubcgif/iag/sftwrdocs/em1dfm/bg.pdf

Farquharson, C.G., Oldenburg, D.W., and Routh, P.S., 2003, Simultaneous 1D inversion of loop-loop electromagnetic data for magnetic susceptibility and electrical conductivity: Geophysics, v. 68, no. 6, p. 1857-1869.

Fraser, D.C., 1978, Resistivity mapping with an airborne multicoil electromagnetic system: Geophysics, v. 43, p. 144-172.

Geosoft Inc., 2010, Oasis Montaj Users Manual Version 7.2, 297 p, accessed June 2, 2010, at: www.geosoft.com..

Haber, E., and Oldenburg, D., 2000, A GCV based method for nonlinear ill-posed problems: Computational Geosciences, v. 4, no. 1, p. 41-63. 
Hodges, G., 2004, Practical inversions for helicopter electromagnetic data:

Proceedings, Symposium on the Application of Geophysics to Engineering and Environmental Problems, Environmental and Engineering Geophysical Society, $10 \mathrm{p}$.

Huang, H. and Fraser, D.C,, 1996, The differential parameter method for muiltifrequency airborne resistivity mapping: Geophysics, v. 55, p. 1327-1337.

Kirsch, R., 2006, Groundwater geophysics—A tool for hydrogeology, Springer-Verlag, Berlin, Heidelberg, $489 \mathrm{p}$.

Korus, J.T., and Divine, D.P., 2007, The Eastern Nebraska Water Resources Assessment (ENWRA); Geological Society of America Abstracts with Programs, vol. 39 , no. 6 , p. 525 .

Oldenburg, D.W., and Li, Y., 1999, Estimating depth of investigation in dc resistivity and IP surveys: Geophysics, v. 64, no. 2, p. 403-416.

Paine, J. G., and Minty, B. R. S., 2005, Airborne hydrogeophysics, in Rubin, Yoram, and Hubbard, S. S. (eds.), Hydrogeophysics: The Netherlands, Springer, Water Science and Technology Library, v. 50, p. 333-357.

Rubin, Y., and Hubbard, S. S., 2005, Hydrogeophysics: The Netherlands, Springer, Water Science and Technology Library, v. 50, 523 p.

Sharma, P.V., 2002 (reprinted), Environmental and Engineering Geophysics, Cambridge University Press, $472 \mathrm{p}$.

Siemon, B., 2006, Electromagnetic methods-frequency domain: Airborne techniques. In: Kirsch, R. (ed.), Groundwater Geophysics—A tool for hydrogeology, SpringerVerlag, Berlin, Heidelberg, 155-170.

Smith, B.D., Abraham, J.A., Cannia, J.C., and Hill, P., 2009, Helicopter electromagnetic and magnetic geophysical survey data for portions of the North Platte and Lodgepole Creek, Nebraska, June 2008: U.S. Geological Survey Open-File Report 2009-1110, p. 28.

Smith, B.D., Cannia, J.C., and Abraham, J.D., 2010, Design of reconnaissance helicopter electromagnetic and magnetic geophysical surveys of the North Platte River and Lodgepole Creek, Nebraska: American Geophysical Union Annual Meeting, San Francisco, 1 p. 
Smith, B.D., Irvine, R., Blome, C.D., Clark, A.K., and Smith, D.V., 2003, Preliminary results, helicopter electromagnetic and magnetic survey of the Seco Creek Area, Medina and Uvalde counties, Texas: Proceedings for the Symposium on the Application of Geophysics to Environmental and Engineering Problems, San Antonio, Texas, $15 \mathrm{p}$.

Smith, B.D., Thamke, J.N., Cain, M.J., Tyrrell, C., and Hill, P.L., 2006, Helicopter electromagnetic and magnetic survey maps and data, East Poplar oil field area, Fort Peck Indian Reservation, northeastern Montana, August 2004, U.S. Geological Survey Open-File Report 2006-1216, 23 p., 1 plate.

Smith, B.D., Grauch, V.J.S., McCafferty, A.E., Smith, D.V., Rodriguez, B.R., Pool, D.R., Deszcz-Pan, M., and Labson, V.F., 2007, Airborne electromagnetic and magnetic surveys for ground-water resources: A decade of study by the U.S. Geological Survey, in, "Proceedings of Exploration 07: Fifth Decennial International Conference on Mineral Exploration" edited by B. Milkereit, 2007, p. 895-899.

Smith, B.D., Abraham, J.D., Cannia, J.C., Steele, G.V., and Hill, P., 2008a, Helicopter electromagnetic and magnetic geophysical survey data, Oakland, Ashland, and Firth study areas, eastern Nebraska, March 2007, U.S. Geological Survey OpenFile Report 2008-1018, 31 p., 1 plate.

Smith, B.D., Abraham, J.D., Cannia, J.C., Steele, G.V., and Peterson, S.M., 2008b, Helicopter electromagnetic surveys for hydrological framework studies in Nebraska, Eos Transactions. AGU, v.89, no. 53, Fall Meet. Supplement, Abstract NS43B-1190, 1 p.

Smith, B.D., Blome, C.D., Smith, D.V., Scheirer, D.D., Deszcz-Pan, M., 2008c, Geophysical surveys to characterize the hydrogeology of the Arbuckle Uplift, south-central Oklahoma: Symposium on Environmental and Engineering Geophysics, Philadelphia, 2008, Annual Meeting Proceedings, p. 539-548.

Smith, R.S. and O'Connell, M.D., 2005, Interpolation and gridding of aliased geophysical data using constrained anisotropic diffusion to enhance trends: Geophysics, v. 70, no. 5, p. 121-127.

Webring, Michael, 1981, MINC: A gridding program based on minimum curvature: U.S. Geological Survey Open-File Report 81-1224, 12 p. 
Won, I.J., 1990, Diagnosing the Earth: Ground-water monitoring review, summer 1990, National Ground Water Association, 2 p. 


\section{APPENDIX I: Geological Society of America Poster}

Preliminary Results from Helicopter Electromagnetic Surveys over a Paleovalley Aquifer in Eastern Nebraska

The poster is provided in the REPORTS folder as

ENWRA_GSA_20091310.pdf. 


\section{APPENDIX II: Fugro Geophysical Report}

The contractor's report (R09007.pdf) is given in the REPORTS folder.

(This report was prepared by non-USGS authors and did not go through

USGS peer review processes and therefore may not adhere to USGS editorial standards) 